\title{
Changes in Cucumber Rhizosphere Bacillus spp. Abundance and Community Structure During Long-Term Continuous Monocropping
}

\author{
Muhammad Khashi u Rahman ${ }^{1,2}$, Changli $M^{1,2}$, Fengzhi Wu ${ }^{1,2 *}$, Xingang Zhou ${ }^{1,2 * *}$ \\ ${ }^{1}$ Key Laboratory of Biology and Genetic Improvement of Horticultural Crops (Northeast Region), \\ Ministry of Agriculture and Rural Affairs, Northeast Agricultural University, Harbin, China \\ ${ }^{2}$ College of Horticulture and Landscape Architecture, Northeast Agricultural University, Harbin, China
}

Received: 12 January 2020

Accepted: 2 April 2020

\begin{abstract}
Continuous monocropping has been a traditional way of cropping system in most parts of the world. It is important to study its effects on soil microbial communities, which are important element of any agroecosystem functioning and for both plant and soil health. In this study, we used real-time PCR and PCR-denaturing gel electrophoresis (PCR-DGGE) techniques to analyze changes in Bacillus spp. abundance, diversity and community structure in continuously monocropped cucumber (Cucumis sativus L.) rhizosphere during nine cropping seasons (after every 2 seasons i.e. 1, 3, 5, 7, 9). Results showed that continuous monocropping significantly changed the Bacillus spp. abundance, diversity and community structure, and the effect was in course of time. The abundance of Bacillus spp. increased up to $5^{\text {th }}$ cropping season and then decreased in following cropping seasons. The number of DGGE bands, Shannon-Wiener Index and Evenness indexes decreased during $3^{\text {rd }}$ cropping season and, after that, increasing trend was observed up to $9^{\text {th }}$ cropping season. These results suggest that the diversity of crop specific Bacillus spp. might start increasing but overall abundance of those keep decreasing after a specific period of time during long-term cucumber continuous monocropping.
\end{abstract}

Keywords: allelopathy, bacterial community, plant-microbe interaction, soil sickness

\section{Introduction}

To meet the increasing demand of food for the growing world population, it is necessary to take timely measures through sustainable improvement of agricultural productivity [1]. Sustainable agriculture is

*e-mail: fzwu2006@aliyun.com

**e-mail: xingangzhou@yahoo.com not all about producing high output crops in short period of time, but rather developing and maintaining a healthy environment for handsome production [2]. For that, land management practices disproportionately impact on soil functioning and agricultural productivity [3]. Studies have shown that selection of proper cropping system (i.e. intercropping, crop rotation, cover crops) could maintain soil organic $\mathrm{C}$, facilitate biological functioning and improve overall soil physical properties [4-6]. In contrary, when we the grow the same crop on the same piece of land repeatedly, it causes accumulation 
of autotoxins in soil, mostly termed as autotoxicity [7]. Autotoxicity lead to soil sickness by alteration in soil microbial community, increase in soil-born pests and disturbance in soil physical and chemical properties $[8,9]$. According to Cesarano et al. [10], soil sickness is induced by plant itself which rises unfavorable conditions for plant vegetative and reproductive growth, ultimately resulting in lower production.

Soil microorganisms are one of the largest biodiversity reservoirs and are an important element of any agroecosystem [11, 12]. They play critical roles in different plant-soil biochemical processes such as mediation of carbon and nutrient cycles in ecosystem $[13,14]$. The lost in soil microbial diversity could alter whole functioning and stability of any agroecosystem which has been recently a threat for sustainable agriculture $[15,16]$. Bacillius, a group of mostly plant beneficial bacterial species, is ubiquitous in agricultural systems and population of this genera occur abundantly in most of the rhizosphere soils [17]. Multiple species of Bacillus have been found promoting plant growth by affecting directly i.e. by synthesizing plant hormones, increasing mineral nutrient uptake by fixing atmospheric nitrogen $(\mathrm{N})$ and soil phosphorus (P) mineralization, while other species can produce antibiotic metabolites to suppress plant pathogen [18]. In many areas, the overall yield of cucumber (Cucumis sativus L.) has been decreased because of continuous monocropping system [25]. One of the explanations for this could be that continuous monocropping have found to be affecting negatively on rhizosphere Bacillus spp. in several crops $[8,9,19]$. However, long-term effects of continuous monocropped cucumber have yet to be disclose.

Since most of the past studies were conducted on single or few monocropping seasons, it would be interesting to investigate long-term effects of cucumber monocropping on rhizosphere Bacillus spp. community. To understand the mechanism of changes in certain microbial community, we monitored Bacillus spp. community in rhizosphere of continuously monocropped cucumber for nine cropping seasons with the aim to analyze how its abundance, diversity and community structure affected by long-term continuous monocropping. We hypothesized that (1) long-term continuous monocropping will negatively affect Bacillus spp. abundance, diversity and community structure, and (2) this effect will be duration dependent.

\section{Materials and Methods}

\section{Plant Material and Greenhouse Experiment}

Cucumber Jinlv 3, which is a famous cultivar in northeast China, was used in a pot experiment conducted from April 2005 to April 2009 in a greenhouse located in the Horticulture Experimental Station in Northeast Agricultural University, Harbin, China (45ํำ'N, $\left.126^{\circ} 37^{\prime} \mathrm{E}\right)$. Each year, cucumber was cultivated twice (April-July, July-October). Each pot contained $8 \mathrm{~kg}$ of soil, which was collected (for first cropping season) from the upper layer of grass covered open field in the same Horticulture Experimental Station, undisturbed for $\geq 15$ years. The soil used in experiment was black soil with sandy loam texture, containing available N: $89.02 \mathrm{mg} \mathrm{kg}^{-1}$; available P: $63.36 \mathrm{mg} \mathrm{kg}^{-1}$; available $\mathrm{K}$ : $119.15 \mathrm{mg} \mathrm{kg}^{-1}$; organic matter: $3.67 \%$, and with $\mathrm{EC}(1: 2.5, \mathrm{w} / \mathrm{v}), 0.33 \mathrm{mS} \mathrm{cm}^{-1}$; and $\mathrm{pH}(1: 2.5, \mathrm{w} / \mathrm{v})$, 7.78 .

Before germinated in dark at $28^{\circ} \mathrm{C}$, cucumber seeds were sterilized with $2.5 \% \mathrm{NaClO}$ for 10 minutes and washed thoroughly with distilled water. Germinated seedlings were then transplanted at four true leaves stage to experimental pots (one seedling per pot) on April 25 and July 25 of each year for each cropping seasons. After completion of first experiment, soil was kept in pots to use for following season experiment, up to $9^{\text {th }}$ cropping. Each cropping season contained a total of 60 pots which were placed randomly in the greenhouse. Fertilizers were applied according to traditional recommendation with decomposed swine manure (organic matter: 15\%; N: 0.5\%; P: $0.5 \%$; $\mathrm{K}: 0.4 \%$ ). For top-dressing, urea fertilizer (N: $46 \%$ ) was used at the rate of $25 \mathrm{~g}$ per pot after 30 days of transplantation. Ground water was applied twice a week to maintain proper suitable moisture of $55 \pm 2$ of water holding capacity and weeds were removed manually.

\section{Sample Collection and DNA Extraction}

The soil samples were collected from five plants for each replicate as previously described by Zhou et al. [20] three times (on 30, 40 and 50 days of transplanting). Collected samples were promptly stored at $-70^{\circ} \mathrm{C}$ for soil microbial DNA extraction. DNA was extracted using the PowerSoil Kit (MO BIO Laboratories, Inc., Carlsbad, CA, USA). The amount and purity of extracted DNA was estimated spectrophotometrically by measuring the optical density at 260 and $280 \mathrm{~nm}$, and DNA was stored at $-20^{\circ} \mathrm{C}$ for further analysis.

\section{PCR-DGGE Analysis}

The community structure of Bacillus spp. was estimated through PCR-DGGE analysis. PCR amplification for Bacillus spp. was carried out using nested primer sets $\mathrm{BacF} / \mathrm{BacR}$ and $\mathrm{F} 338 \mathrm{GC} / \mathrm{R} 518$ as previously described by Zhou et al. [9]. The PCR conditions were: $95^{\circ} \mathrm{C}$ for $5 \mathrm{~min}$ followed by 28 cycles of $95^{\circ} \mathrm{C}$ for $30 \mathrm{~s}, 56{ }^{\circ} \mathrm{C}$ for $45 \mathrm{~s}, 72^{\circ} \mathrm{C}$ for $90 \mathrm{~s}$, and final extension at $72^{\circ} \mathrm{C}$ for $10 \mathrm{~min}$. For DGGE analysis, $6 \%$ (w/v) acrylamide gel with $56-60 \%$ denaturing gradient was used. A 1xTAE (Tris-acetate-EDTA) buffer was used for running gel for $14 \mathrm{~h}$ under conditions of $60^{\circ} \mathrm{C}$ and $80 \mathrm{~V}$ with a Dcode universal mutation detection 
system (Bio-Rad Lab, LA, USA). Gel was stained in 1:3300 (v/v) GelRed (Biotium, USA) nuclic acid staining solution promptly after electrophoresis. Finally, an AlphaImager HP imaging system (Alpha Innotech Corp., CA, USA) was used to photograph the DGGE profiles under UV light.

\section{Real-Time PCR Assay}

To estimate total abundance of Bacillus spp., a realtime PCR assay was carried out using primer set of $\mathrm{BacF} / \mathrm{BacR}$ as described earlier [9]. The protocol set in the assay was: $95^{\circ} \mathrm{C}$ for $5 \mathrm{~min}$; followed by 30 cycles of $95^{\circ} \mathrm{C}$ for $30 \mathrm{~s}, 65^{\circ} \mathrm{C}$ for $30 \mathrm{~s}$ and $72^{\circ} \mathrm{C}$ for $90 \mathrm{~s}$; and finally, an extension at $72^{\circ} \mathrm{C}$ for $10 \mathrm{~min}$. A dilution series $\left(10^{2}-10^{8}\right)$ of plasmid DNA containing Bacillus spp. $16 \mathrm{~S}$ rRNA genes was used to develop a standard curve. For negative control, sterilized water was used to replace the template. Amplification of each replicate was done in triplicate. To confirm the specificity of the product, melting curve analysis and agarose gel electrophoresis were used. The initial copy number of target gene were determined by comparing obtained threshold cycle $(C t)$ value of each sample with standard curve.

\section{Statistical Analysis}

For the analysis of DGGE profiles banding patterns, the Quantity One v4.5 (Bio-Rad Lab, LA, USA) was used. To compare the banding pattern between the samples, principle component analysis (PCA) was used with Canoco for Windows 4.5 software (Plant Research International, Wageningen, the Netherlands). The Bacillus spp. community diversity parameter including number of bands, Shannon-Wiener and evenness indexes were calculated as described previously by Zhou et al. [20]. Data was analyzed by analysis of variance (ANOVA), and the mean values between treatments for Bacillus spp. diversity parameters were compared using Tukey's honestly significant difference (HSD) test at probability level of $<0.05$.

\section{Results and Discussion}

The soil functioning carried out by microbial communities mainly decides the productivity and sustainability of agriculture system [21]. It is well understood now that agricultural practices such as tillage, fertilization and cropping system could
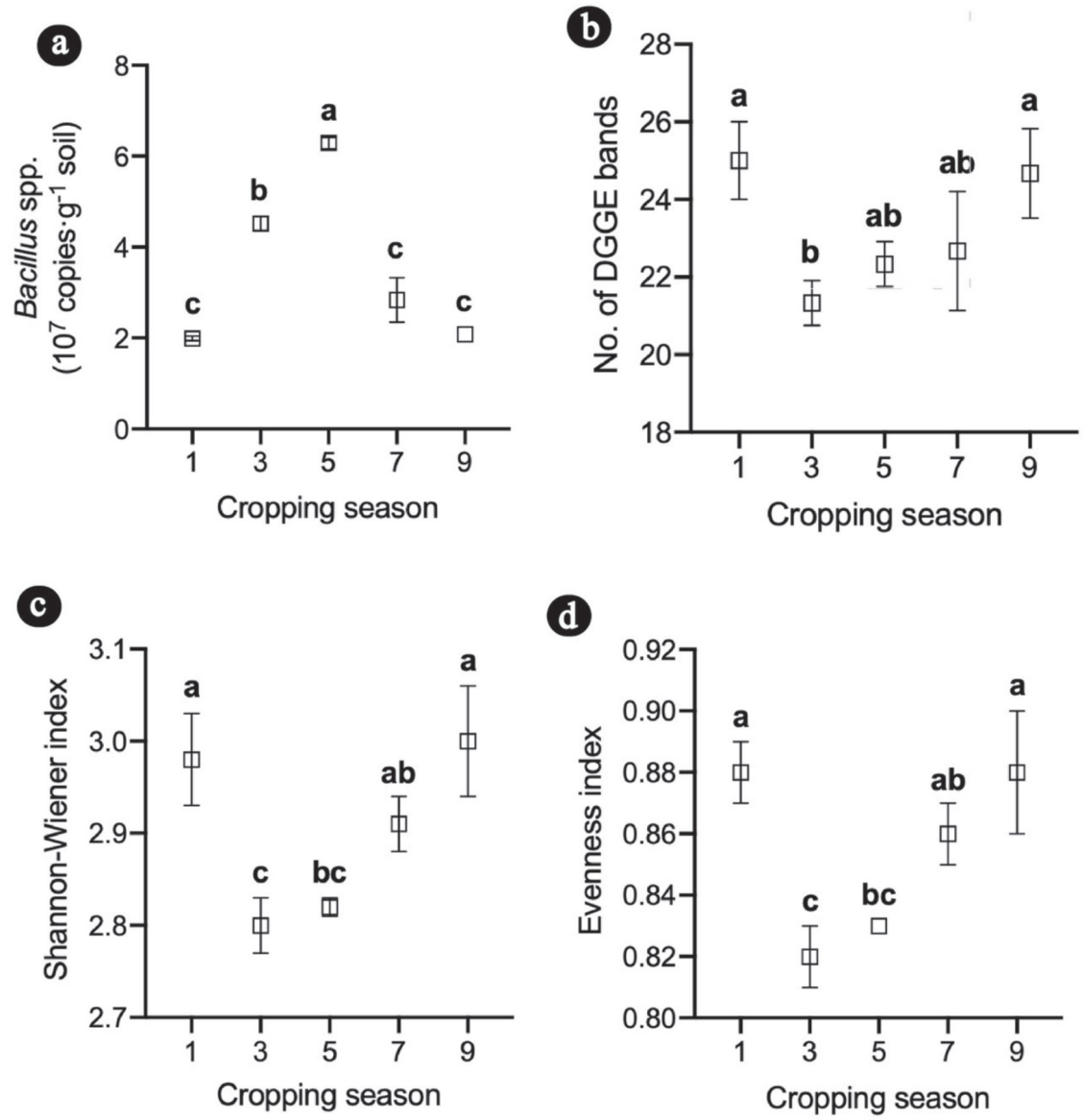

Fig. 1. Changes in Bacillus spp. community abundance a), and diversity parameters including no. of DGGE bands b), Shannon-Wiener c) and evenness d) indexes during different cropping seasons. The values of each season in particular figure labeled with different letter are significantly different $(\mathrm{P}<0.05$; Tukey's HSD test). 
a
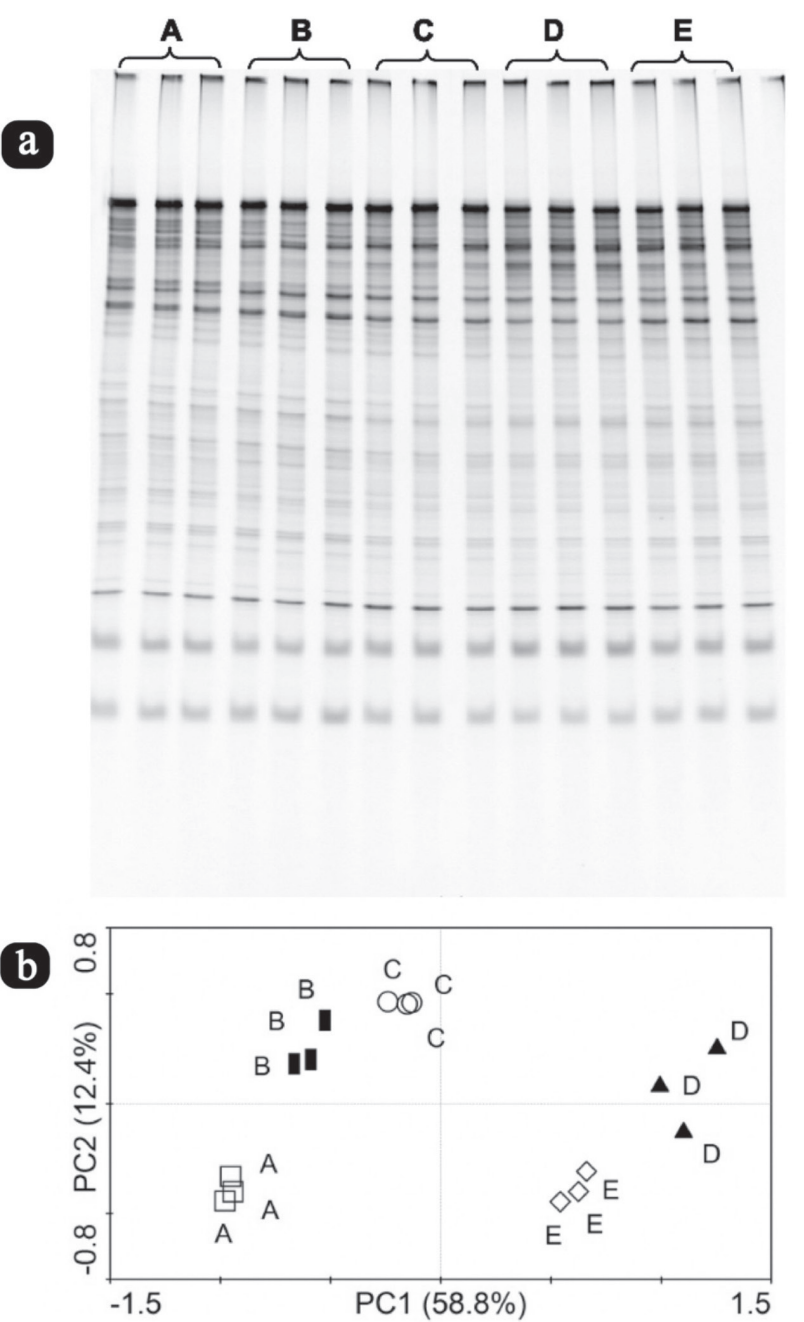

Fig. 2. The DGGE map a) and PCA diagram b) of Bacillus spp. community during different cropping seasons. Capital letters in diagrams indicate the no of cropping season as A: 1, B: 3, C: 5, D: 7, E: 9 .

significantly influence changes in soil microbial community $[20,22]$. In this study, we used real-time PCR and PCR-denaturing gel electrophoresis (PCRDGGE) techniques to monitor the changes in Bacillus spp. community abundance, diversity and structure in cucumber rhizosphere during pot experiments for 9 cropping seasons.

\section{Changes in Bacillus spp. Community Abundance and Diversity}

Real-time PCR analysis showed a significant difference in Bacillus spp. abundance between $1^{\text {st }}, 3^{\text {rd }}$ and $5^{\text {th }}$ cropping seasons, while there was no difference found between abundance during season 1, 7 and 9 of continuous monocropping (Fig. 1a). The highest abundance was examined during $5^{\text {th }}$ cropping season followed by $3^{\text {rd }}$ cropping season, while the Bacillus spp. community was lowest during $1^{\text {st }}, 7^{\text {th }}$ and $9^{\text {th }}$ seasons among all 9 monitored cropping seasons. Our results showed an increasing trend in Bacillus spp. abundance in the beginning up to $5^{\text {th }}$ cropping season, however, it decreased gradually to $1^{\text {st }}$ cropping season at the end of experiment. The abundance of Bacillus spp. was lowest during first cropping season and reached to the highest value during $5^{\text {th }}$ cropping season among all examined 9 cropping seasons. In contrary, DGGE analysis revealed that continuously monocropping did significantly affect number of bands (Fig. 1b), Shannon-Wiener (Fig. 1c) and evenness (Fig. 1d) indexes of samples from $1^{\text {st }}$, $3^{\text {rd }}$ and rest of cropping seasons $(\mathrm{P}<0.05)$. The highest number of bands were found during $1^{\text {st }}$ and $9^{\text {th }}$ followed by $7^{\text {th }}$ and $5^{\text {th }}$ cropping season, respectively, while least were during $3^{\text {rd }}$ cropping season. Almost the same trend was seen in Shannon-Wiener and evenness indexes of Bacillus spp. diversity parameters. These results of diversity parameters showed that the diversity of Bacillus spp. decreased until $3^{\text {rd }}$ cropping season but increased afterward to $1^{\text {st }}$ cropping season at $9^{\text {th }}$ cropping season.

When same crop is grown again and again on same piece of land, the autotoxins released through root exudates and from plant debris start accumulate in root zone $[23,24]$. An increasing number of studies have shown that the accumulation of plant released phenolic compounds due to continuous monocropping and exogenously applied autotoxins can alter the composition of soil microbial communities [25-29] including plant beneficial soil microbial species such as Bacillus spp. [30-32]. According to Zhou and $\mathrm{Wu}$ [33], vanillic acid significantly reduced abundance and changed community structure of Bacillus spp. during cucumber monocropping. Similarly, another autotoxin compound, vanillin, adversely affected Bacillus spp. community composition in cucumber rhizosphere soil [31]. Soil assembled autotoxin compounds can also damage plant roots and increase ion leakage rate and affect rhizosphere microbial communities [34]. In this study, the decreasing trend in Bacillus spp. abundance after $5^{\text {th }}$ cropping season could be due to increase in higher accumulation of cucumber autotoxins in soil with increase in number of cropping seasons. For example, Li et al. [35] found that the accumulation of autotoxin i.e. $p$-hydroxybenzoic acid, ferulic acid, cinnamic acid and $p$-coumaric acid increased with increase in number of monocropping seasons of strawberry. Concerning the contrary results of Bacillus spp. diversity parameters, one can assume that growing same crop consistently without introduction of new crop might increase abundance of crop-specific bacterial strains resulting an increase in Bacillus spp. diversity with increase in number of cropping seasons.

\section{Changes in Bacillus spp. Community Structure}

The DGGE analysis showed an obvious visual difference in banding pattern of Bacillus spp. among 9 
cropping seasons (Fig. 2a). PCA analysis showed that continuously monocropped cucumber totally changed Bacillus spp. community structure during 9 consecutive cropping seasons as separated samples can be seen in Fig. 2b. PCA plot of DGGE banding pattern of Bacillus spp. explained $58.8 \%$ and $12.4 \%$ in first and $2^{\text {nd }}$ PCA axis, respectively. In particular, the difference between $3^{\text {rd }}$ and $5^{\text {th }}$ cropping season with the rest of cropping seasons was more obvious. It has examined that several factors, such as crop type, cropping system, tillage management and plant growth stage, could significantly affect rhizosphere microbial communities [27, 36]. Among these factors, cropping system is one of the key factors which could potentially affect soil microbial structure [37]. Similarly, in our study, PCA analysis can distinguish Bacillus spp. community structure in rhizosphere samples taken from different cropping seasons (Fig. 2b). This might be due to different root exudation pattern, because root exudates are the main derivers for rhizosphere microbial compositions [38]. Another possible reason could be the accumulation of autotoxin in potting soil after regular cucumber monocropping. The phenolic acids are revealed to greatly affect soil bacterial community structure in previous studies [31, 39]. For example, the community structure of Bacillus spp. was comprehensively altered by exogenously application of phenolic compounds [33].

\section{Conclusion}

Long-term monocropping of cucumber could decrease rhizosphere Bacillus spp. community abundance and changing community structure. From these results, we speculate that the accumulation level of autotoxins with long-term and constantly planting cucumber increased which resulted in lowering the abundance and changing in community structure of Bacillus spp. with increase in number of cropping seasons. This study has provided us great insights that how long-term continuously monocropping could affect plant beneficial microbial genre such as Bacillus spp.

\section{Acknowledgment}

This work was supported by the the Natural Science Foundation of Heilongjiang Province (YQ2019C009), National Natural Science Foundation of China (31772361), China Agricultural Research System (CARS-23-B-10), and Longjiang Scholars Program (Q201920).

\section{Conflict of Interest}

The authors declare no conflict of interest to disclose.

\section{References}

1. CAlicioglu O., FLAMMiNi A., BRACCO S., BELLÙ L., SIMS R. The future challenges of food and agriculture: An integrated analysis of trends and solutions. Sustainability, 11 (1), 222. 2019.

2. WALL P.C. Tailoring conservation agriculture to the needs of small farmers in developing countries: an analysis of issues. J. Crop Improv., 19 (1-2), 137, 2007.

3. POWLSON D.S., GREGORY P.J., WHALLEY W.R., QUINTON J.N., HOPKINS D.W., WHITMORE A.P., HIRSCH P.R. GOULDING K.W. Soil management in relation to sustainable agriculture and ecosystem services. Food policy, 36, S72-S87. 2011.

4. MALÉZIEUX E., CROZAT Y., DUPRAZ C., LAURANS M., MAKOWSKI D., OZIER-LAFONTAINE H., RAPIDEL B., DE TOURDONNET S., VALANTINMORISON M. Mixing plant species in cropping systems: concepts, tools and models: a review. In Sustainable Agriculture. Springer, Dordrecht, 329-, 2009

5. ARSHAD M., NAWAZ R., AHMAD S., SHAH G.A., FAIZ F., AHMAD N., IRSHAD M.A., RANAMUKHAARACHCHI S.L. Growth, Yield and Nutritional Performance of Sweet Sorghum and Legumes in Sole and Intercropping Influenced by Type of Legume, Nitrogen Level and Air Quality. Pol. J. Environ. Stud., 29 (1), 533, 2019.

6. JIN X., ZHANG J., SHI Y., WU F., ZHOU X. Green manures of Indian mustard and wild rocket enhance cucumber resistance to fusarium wilt through modulating rhizosphere bacterial community composition. Plant Soil, 441 (1-2), 283, 2019.

7. ZHOU X., GAO D., LIU J., QIAO P., ZHOU X., LU H., WU X., LIU D., JIN X., WU F. Changes in rhizosphere soil microbial communities in a continuously monocropped cucumber (Cucumis sativus L.) system. Eur. J. Soil Biol., 60, 1, 2014.

8. LING N., DENG K., SONG Y., WU Y., ZHAO J., RAZA W., HUANG Q., SHEN Q. Variation of rhizosphere bacterial community in watermelon continuous monocropping soil by long-term application of a novel bioorganic fertilizer. Microbiol. Res., 169 (7-8), 570, 2014.

9. ZHOU X., GAO D., ZHAO M., ZHANG J., LI L., WU F. Dynamics of soil bacterial communities in Jerusalem artichoke monocropping system. Allelopathy J., 39, 167, 2016.

10. CESARANO G., ZOTTI M., ANTIGNANI V., MARRA R., SCALA F., BONANOMI G. Soil sickness and negative plant-soil feedback: A reappraisal of hypotheses. J. Plant Pathol., 99 (3), 545, 2017.

11. CALDERÓN K., SPOR A., BREUIL M.C., BRU D., BIZOUARD F., VIOLLE C., BARNARD R.L., PHILIPPOT L. Effectiveness of ecological rescue for altered soil microbial communities and functions. ISME J., 11 (1), 272, 2017.

12. LIU L., WANG Y., GAI Z., LIU D., WU P., WANG B., ZOU C., LI C., YANG F. Responses of soil microorganisms and enzymatic activities to alkaline stress in sugar beet rhizosphere. Pol. J. Environ. Stud., 29 (1), 739, 2019.

13. WALDROP M.P., FIRESTONE M.K. Response of microbial community composition and function to soil climate change. Microb. Ecol., 52 (4), 716, 2006.

14. BOUZOUMITA A., METOUI M., JEMNI M., KABAEIR N., BELHOUCHETTE K., FERCHICHI A. The efficacy of various bacterial organisms for biocontrol of fusarium 
root rot of olive in Tunisia. Pol. J. Environ. Stud., 29 (1), $11,2020$.

15. SINGH J.S., GUPTA V.K. Soil microbial biomass: a key soil driver in management of ecosystem functioning. Sci. Total Environ., 634, 497. 2018.

16. BENDER S.F., WAGG C. VAN DER HEIJDEN M.G. An underground revolution: biodiversity and soil ecological engineering for agricultural sustainability. Trends Ecol. Evol., 31 (6), 440, 2016.

17. GOVINDASAMY V., SENTHILKUMAR M., MAGHESHWARAN V., KUMAR U., BOSE P., SHARMA V., ANNAPURNA K. Bacillus and Paenibacillus spp.: potential PGPR for sustainable agriculture. In Plant growth and health promoting bacteria. Springer, Berlin, Heidelberg. 333, 2010.

18. VAN LOON L.C. Plant responses to plant growthpromoting rhizobacteria. In New perspectives and approaches in plant growth-promoting Rhizobacteria research. Springer, Dordrecht. 243, 2007.

19. SANGUIN H., SARNIGUET A., GAZENGEL K., MOËNNE-LOCCOZ Y., GRUNDMANN G.L. Rhizosphere bacterial communities associated with disease suppressiveness stages of take-all decline in wheat monoculture. New Phytol., 184 (3), 694, 2009.

20. ZHOU X., YU G., WU F. Effects of intercropping cucumber with onion or garlic on soil enzyme activities, microbial communities and cucumber yield. Eur. J. Soil Biol., 47 (5), 279, 2011.

21. BEVER J.D., PLATT T.G., MORTON E.R. Microbial population and community dynamics on plant roots and their feedbacks on plant communities. Annu. Rev. Microb., 66, 265, 2012.

22. GARBEVA P., VAN ELSAS J.D., VAN VEEN J.A. Rhizosphere microbial community and its response to plant species and soil history. Plant soil, 302 (1-2), 19, 2008.

23. ZHOU X., WU F. p-Coumaric acid influenced cucumber rhizosphere soil microbial communities and the growth of Fusarium oxysporum f. sp. cucumerinum Owen. PloS one, 7 (10), e48288, 2012.

24. TIAN Y., FENG F., ZHANG B., LI M., WANG F., GU L., CHEN A., LI Z., SHAN W., WANG X, CHEN X. Transcriptome analysis reveals metabolic alteration due to consecutive monoculture and abiotic stress stimuli in Rehamannia glutinosa Libosch. Plant Cell Rep., 36 (6), 859, 2017

25. ZHOU X., LIU J., WU F. Soil microbial communities in cucumber monoculture and rotation systems and their feedback effects on cucumber seedling growth. Plant Soil, 415 (1-2), 507, 2017.

26. ZHAO Q., XIONG W., XING Y., SUN Y., LIN X, DONG, Y. Long-term coffee monoculture alters soil chemical properties and microbial communities. Sci. Rep., 8 (1), 6116, 2018

27. ZHOU X.G., WANG J., JIN X., LI D.L., SHI Y.J., WU, F.Z. Effects of selected cucumber root exudates components on soil Trichoderma spp. communities. Allelopathy J., 47 (2), 257, 2019.

28. JIA H.T., LIU J.Y., SHI Y.J., LI D.L., WU F.Z., ZHOU X.G. Characterization of cucumber rhizosphere bacterial community with high-throughput amplicon sequencing. Allelopathy J., 47 (1), 103, 2019.

29. JIN X., WU F., ZHOU X. Different toxic effects of ferulic and $\mathrm{p}$-hydroxybenzoic acids on cucumber seedling growth were related to their different influences on rhizosphere microbial composition. Biol. Fertil. Soils, 56 (1), 125, 2020.

30. JIA H.T., CHEN S.C., YANG S.Y., SHEN Y.H., QIAO P.L., WU F.Z., ZHOU X.G. Effects of vanillin on cucumber rhizosphere bacterial community. Allelopathy J., 44 (2), 191, 2018.

31. ZHOU X.G., WANG Z.L., PAN D.D., WU F.Z. Effects of vanillin on cucumber (Cucumis sativus L.) seedling rhizosphere Bacillus and Pseudomonas spp. community structures. Allelopathy J., 44 (2), 255, 2018.

32. KHASHI U RAHMAN M., ZHOU X.G., WU F.Z. The role of root exudates, CMNs, and VOCs in plant-plant interaction. J. Plant Interact., 14 (1), 630, 2019.

33. ZHOU X., WU F. Vanillic acid changed cucumber (Cucumis sativus L.) seedling rhizosphere total bacterial, Pseudomonas and Bacillus spp. communities. Sci. Rep., 8 (1), 4929, 2018

34. YU J.Q., MATSUI Y. Effects of root exudates of cucumber (Cucumis sativus) and allelochemicals onion uptake by cucumber seedlings. J. Chem. Ecol., 23 (3), 817, 1997.

35. LI X., LEWIS E.E., LIU Q., LI H., BAI C., WANG, Y. Effects of long-term continuous cropping on soil nematode community and soil condition associated with replant problem in strawberry habitat. Sci. Rep., 6 (1), 30466 , 2016.

36. XU Y., WANG G., JIN J., LIU J., ZHANG Q., LIU, X. Bacterial communities in soybean rhizosphere in response to soil type, soybean genotype, and their growth stage. Soil Biol. Biochem., 41 (5), 919, 2009.

37. ASHWORTH A.J., DEBRUYN J.M., ALLEN F.L. RADOSEVICH M., OWENS P.R. Microbial community structure is affected by cropping sequences and poultry litter under long-term no-tillage. Soil Biol. Biochem., 114, 210, 2017.

38. SASSE J., MARTINOIA E., NORTHEN T. Feed your friends: do plant exudates shape the root microbiome? Trends Plant Sci., 23 (1) 25, 2018.

39. QU X.H., WANG J.G. Effect of amendments with different phenolic acids on soil microbial biomass, activity, and community diversity. Appl. Soil Ecol., 39 (2), 172, 2008. 